\title{
Tobacco stalk lignocellulosic nanofibers characterization for pharmaceutical
}

\section{applications}

\author{
Caracterização de nanofibras lignocelulósicas de caule de tabaco para aplicações farmacêuticas \\ Caracterización de nanofibras lignocelulósicas de tallos de tabaco para aplicaciones farmacéuticas
}

Received: 10/25/2021 | Reviewed: 11/02/2021 | Accept: 11/09/2021| Published: 11/13/2021

\author{
Keth Ribeiro Garcia ${ }^{1}$ \\ ORCID: https://orcid.org/0000-0003-1186-080X \\ Universidade de Caxias do Sul, Brazil \\ E-mail:k1rgarcia@gmail.com \\ Valeria Weiss-Angeli \\ ORCID: https://orcid.org/0000-0002-1019-7949 \\ Universidade de Caxias do Sul, Brazil \\ E-mail: vwangeli@ucs.br \\ Letícia Scherer Koester ${ }^{3}$ \\ ORCID: https://orcid.org/0000-0002-1043-5855 \\ Universidade Federal do Rio Grande do Sul, Brazil \\ E-mail: leticia.koester@ufrgs.br \\ Venina dos Santos ${ }^{1}$ \\ ORCID: https://orcid.org/0000-0002-6344-8094 \\ Universidade de Caxias do Sul, Brazil \\ E-mail: vsantos2@ucs.br \\ Rosmary Nichele Brandalise ${ }^{1}$ \\ ORCID: https://orcid.org/0000-0002-4719-6093 \\ Universidade de Caxias do Sul, Brazil \\ E-mail: rnbranda@ucs.br
}

\begin{abstract}
Lignocellulosic nanofibers derived from tobacco stalk can have countless applications in polymers composites, textile, cosmetics, and pharmaceuticals. Thus, it is important to evaluate biomass characteristics such as the presence of nicotine. In this study, nanofibers were obtained by mechanical fibrillation while cellulose content $(0.5$ and $2.0 \%)$ and drying methods were varied. Nanofibers were characterized by thin layer chromatography, ${ }^{1} \mathrm{H}$ NMR, morphological analysis, $\alpha$-cellulose content, Fourier transform infrared spectroscopy, X-ray diffraction and thermal analysis. Results demonstrate the absence of nicotine in tobacco stalk. The grinding mill process was efficient to produce by freezedrying, nanofibers with fiber's mean diameter of $\sim 30 \mathrm{~nm}$. Solid concentrations can influence the diameter of obtained fibers. Thermal stability increased and crystallinity decreased when alkali treatment was applied. The characterization techniques applied enable the evaluation of tobacco stalk and expanded its application to pharmaceutics.
\end{abstract}

Keywords: Tobacco stalk; Lignocellulosic nanofibers; Cellulose nanofibers; Characterization techniques; CNF.

\section{Resumo}

Nanofibras lignocelulósicas derivadas do caule do tabaco podem ter inúmeras aplicações em compósitos poliméricos, tecidos, cosméticos e produtos farmacêuticos. Assim, é importante avaliar características da biomassa como a presença de nicotina. Neste estudo, as nanofibras foram obtidas por fibrilação mecânica, enquanto o teor de celulose $(0,5$ e 2,0\%) e os métodos de secagem foram variados. As nanofibras foram caracterizadas por cromatografia em camada delgada, ${ }^{1} \mathrm{H}$ RMN, análise morfológica, conteúdo de $\alpha$-celulose, espectroscopia de infravermelho com transformada de Fourier, difração de raios- $X$ e análises térmicas. Os resultados demonstram a ausência de nicotina no caule do tabaco. O processo de moagem foi eficiente para produzir por liofilização, nanofibras com diâmetro médio da fibra de $\sim 30 \mathrm{~nm}$. As concentrações de sólidos podem influenciar o diâmetro das fibras obtidas. A estabilidade térmica aumentou e a cristalinidade diminuiu quando o tratamento alcalino foi aplicado. As técnicas de caracterização aplicadas possibilitaram a avaliação do caule do tabaco e ampliaram sua aplicação na área farmacêutica.

Palavras-chave: Caule de tabaco; Nanofibras lignocelulósicas; Nanofibras de celulose; Técnicas de caracterização; NFC.

\footnotetext{
${ }^{1}$ Programa de Pós-Graduação em Engenharia de Processos e Tecnologias, Universidade de Caxias do Sul (UCS), Brazil

2 Centro de Ciências da Saúde e Biológicas, Curso de Farmácia, Universidade de Caxias do Sul (UCS), Brazil

3

Programa de Pós-Graduação em Ciências Farmacêuticas, Faculdade de Farmácia, Universidade Federal do Rio Grande do Sul (UFRGS), Brazil
} 


\section{Resumen}

Las nanofibras lignocelulósicas derivadas del tallo del tabaco pueden tener innumerables aplicaciones en compuestos de polímeros, textiles, cosméticos y productos farmacéuticos. Por tanto, es importante evaluar las características de la biomasa como la presencia de nicotina. En este estudio, las nanofibras se obtuvieron mediante fibrilación mecánica mientras se variaba el contenido de celulosa $(0,5$ y $2,0 \%)$ y los métodos de secado. Las nanofibras se caracterizaron por cromatografía en camada delgada, $1 \mathrm{H} \mathrm{RMN}$, análisis morfológico, contenido de $\alpha$-celulosa, espectroscopia infrarroja por transformada de Fourier, difracción de rayos X y análisis térmicas. Los resultados demuestran la ausencia de nicotina en el tallo del tabaco. El proceso del molino fue eficiente para producir mediante liofilización, nanofibras con un diámetro medio de fibra de $\sim 30 \mathrm{~nm}$. Las concentraciones de sólidos pueden influir en el diámetro de las fibras obtenidas. La estabilidad térmica aumentó y la cristalinidad disminuyó cuando se aplicó un tratamiento con álcali. Las técnicas de caracterización aplicadas permiten evaluar el tallo del tabaco y ampliar su aplicación a la industria farmacéutica.

Palabras clave: Tallo de tabaco; Nanofibras lignocelulósicas; Nanofibras de celulose; Técnicas de caracterización; NFC.

\section{Introduction}

The present emphasis on green chemistry and on chemical processes, as well as the application of the fundamental principles of the environmentally correct on nanotechnology and on nanomaterials has been a frequent interest target (Trache et al., 2017), chiefly as relates cellulosic materials. Among renewable sources, biomasses of vegetable origin are widely researched since their natural and lignocellulosic origin involves high contents of cellulose in their composition (Poletto et al., 2012b; Trache et al., 2016; Wongsiriamnuay \& Tippayawong, 2010).

Cellulose is the organic compound derived from the most abundant plant biomass on the surface of the earth, having an estimated annual production of $7.5 \times 10^{10}$ tons (Habibi et al., 2010; Jia et al., 2014). The natural polymorphic form is cellulose I (native) which is constituted of two different crystalline forms: I $\alpha$ and $\mathrm{I} \beta$ that can be found together on the same cellulose sample and throughout microfiber (de Souza Lima \& Borsali, 2004; Lavoine et al., 2012; Trache et al., 2016). Besides the native cellulose form, which is thermodynamically less stable, there is also the occurrence of other crystalline structures such as II, III and IV (Klemm et al., 2005; Pachuau, 2015; Trache et al., 2016). However, the most stable crystalline form is cellulose II (Klemm et al., 2005; Lavoine et al., 2012; Trache et al., 2016), it being considered as regenerated cellulose because it is obtained by mercerization (cellulose treatment with sodium hydroxide aqueous solution). To obtain celluloses III $_{\text {I }}$ and III $_{\text {II }}$ cellulose I and II is treated with ammonium. Cellulose IV is formed by the modification of cellulose III (Lavoine et al., 2012).

Nanofibrillated cellulose (NFC), also called nanocellulose (Brinchi et al., 2013; Klemm et al., 2011; Lavoine et al., 2012), belongs to an emerging class of biomaterials having desirable properties, mainly related to the raw material being of relatively low-cost, biodegradable, biocompatible, having higher water absorption capacity and strength and stiffness mechanical properties (Lin \& Dufresne, 2014; Roman, 2015).

The expression "nanocellulose" is generally employed to refer to cellulosic materials having at least one dimension in the nanometric scale and being obtained by different methods. Nanocellulose belongs to three categories according to its production method: a) bacterial cellulose (also known as microbial cellulose or biocellulose), obtained using strains of Acetobacter xylinum (Klemm et al., 2018); b) cellulosic nanocrystals (also called nanowhiskers or nanocrystalline cellulose (NCC), obtained by acidic hydrolysis (Klemm et al., 2011), and c) nanofibrillated cellulose (NFC), obtained by mechanical methods such as micronized milling, microfluidization, cryocrushing, high-intensity ultrasonication and high-pressure homogenization (Abdul Khalil et al., 2014).

Nanofibrillated cellulose from biomass has been gained attention due to its characteristics of high surface area, strength and stiffness combined with high porosity, biodegradability and renewability (Brinchi et al., 2013; Lavoine et al., 2012; Trache et al., 2020) which allowed its application in polymer composites (Kalia et al., 2011) and paperboard panels (Li Xiaoping, Wu Zhangkang, 2014). The challenge now is to extract and characterize these NFCs from renewable sources (Credou \& Berthelot, 2014; Kalia et al., 2011) in order to apply them as byproducts to produce pharmaceuticals and other health products. 
Regarding drug development, some studies have shown nanocellulose films as coatings for tablets to modified release drugs evaluation (Kolakovic et al., 2012, 2013). Furthermore, there are studies concerning the modification of nanocellulose surface to alter tablets disintegration time or to improve the affinity with hydrophobic drugs (Carlsson et al., 2014; Pachuau, 2015). Such properties can aid in the development of solid pharmaceutical forms, such as tablets, having both improved mechanical resistance and solubility features, according to the drug used in the formulation, allowing it to be dissolved quicker or slower.

Several sources of environmentally friendly cellulosic materials have been used to obtain cellulose nanostructures and the most used ones include cotton (Mohanty et al., 2002), birch (Kolakovic et al., 2011) and pineapple leaf fibers (Cherian et al., 2010), whereas few studies were dedicated to evaluating the cellulose content of an unconventional source as tobacco (Agrupis et al., 2000; Agrupis \& Maekawa, 1999; Kulić \& Radojicic, 2011; Shakhes et al., 2011; Tuzzin et al., 2016).

Tobacco (Nicotiana tabacum L.) is a crop of major importance in Brazil and mainly in the Southern region of the country, where in the last 20 years accentuated concentration of cultivation and industrial plants for processing and export could be observed. The country has been leading the international market, and more than $85 \%$ of the tobacco produced in Brazil is negotiated abroad (MDIC, 2020).

Although tobacco is not an eatable plant, its economical relevance worldwide is of utmost importance. Because of the leaves' high-quality grade, tobacco cultivation is only for commercial purposes as cigarettes and cigars (Agrupis \& Maekawa, 1999). After all the leaves are harvested, the stalks remain, which are generally incorporated into the soil (Shakhes et al., 2011). As the tobacco stalk is of lignocellulosic nature, it can be classified as an agricultural waste and converted into a wide variety of chemicals, such as alcohol, sweeteners, prebiotic oligosaccharides, plastics (Akpinar et al., 2010) while also being considered as a lignocellulosic biomass. However, the biggest concern related to this kind of biomass is the presence of noxious substances such as nicotine, especially when the target of the study is to apply it in the development of products for human use.

The purpose of this paper is to obtain lignocellulosic nanofiber from tobacco stalk through micronized grinding and to characterize it in order to enlarge its application considering the 4R's rule (Reducing, Reuse, Repair, Recover and Recycling) as a green, sustainable biomass directed to a possible use as a novel pharmaceutical excipient and exploring its potential functions as binder, diluent and/or disintegrating agent for the preparation of granules and further tablets production.

\section{Materials and Methods}

\subsection{Materials}

Tobacco stalks (Virginia species, crop of 2014/2015) were obtained from Recon INC. (Santa Cruz do Sul- RS, Brazil). Nicotine standard (99.1\%) was purchased from Sigma-Aldrich (Brazil). Methanol, toluene, ethyl acetate, diethylamine and benzene were obtained from Vetec (Brazil), ammonium hydroxide was obtained from Lafan (Brazil). Sodium hydroxide (NaOH) was purchased from Vetec (Brazil); acetic acid was supplied by Dinâmica (Brazil) and deuterated chloroform from SigmaAldrich (Brazil). Distilled water was used.

\subsection{Tobacco stalk pretreatment}

In natura tobacco stalks (Fig. 1a) were oven dried (De Leo, Brazil) at $40 \pm 5^{\circ} \mathrm{C}$ for 10 days and ground in a knife mill (Fig. 1b) (Willye TE 650, Tecnal, Brazil) generating a non-treated tobacco stalk powder (Kaya et al., 2018). After that, the powder was pretreated using the mercerization process. This pretreatment comprises the sample constant heating at $100^{\circ} \mathrm{C}$ and stirred for $90 \mathrm{~min}$ in a $1.0 \%(\mathrm{w} / \mathrm{v}) \mathrm{NaOH}$ solution (Vetec, Brazil) and subsequent $\mathrm{pH}$ neutralization with $20 \%$ (v/v) acetic acid solution (Dinâmica, Brazil) and washing with distilled water followed by filtration (Li Xiaoping, Wu Zhangkang, 2014). The solid portion was used. 


\subsection{Nicotine determination in tobacco stalks}

\subsubsection{Proton nuclear magnetic resonance ( ${ }^{1} \mathrm{H}$ NMR) spectroscopy}

Verification of the nicotine presence in raw tobacco stalk and in treated tobacco stalk was performed by ${ }^{1} \mathrm{H}$ NMR in a Bruker Fourier 300 (Germany) spectrometer operating at $300 \mathrm{MHz}$. Deuterated chloroform $\left(\mathrm{CDCl}_{3}\right)$ was used as solvent. Chemical shifts $(\delta)$ were expressed in parts per million (ppm) (Berger \& Sicker, 2009).

\subsubsection{Thin layer chromatography}

By this method (Wagner \& Bladt, 1996), $1 \mathrm{~g}$ of raw tobacco stalk was mixed with $1 \mathrm{~mL} 10 \%$ ammonia solution (w/v) and extracted with $5 \mathrm{~mL}$ of methanol under reflux for 10 minutes. The filtrate was concentrated with methanol. The solvent system was prepared in the proportion of 70:20:10 (v/v/v) of toluene-ethyl acetate-diethylamine. Silica gel $\mathrm{F}_{254}(\mathrm{Merck}$, Darmstadt, Germany) plates without fluorescence were employed. Raw tobacco stalk powder (i), tobacco leaves powder (ii) and cigarette blend (iii) were used for comparison with nicotine standard (iv) (Sigma-Aldrich, Brazil). Dragendorff's reagent was used as detecting agent. Results were expressed as Retention factor (Rf), which is equal to the distance migrated over the total distance covered by the solvent. Samples were used as received.

\subsection{Tobacco stalk mechanical fibrillation to produce lignocellulose nanofibers}

In order to obtain lignocellulosic nanofibers (TS-NFC), the treated tobacco stalk was transferred to a micronizer mill Masuko® MKCA 6-2J (Japan) (Lavoratti et al., 2016; Nogi et al., 2009; Spence et al., 2011; Tuzzin et al., 2016; Vartiainen et al., 2011) (Fig. 1c). The proportion of treated tobacco stalk and distilled water used in grinding process was $30 \mathrm{~g}$ : $6 \mathrm{~L}$, and $120 \mathrm{~g}$ : $6 \mathrm{~L}$ to obtain theoretical concentrations of $0.5 \%$ and $2.0 \%$ (w/v) lignocellulosic nanofibers suspensions respectively (Fig. 1d). TS-NFC suspensions were processed for 5 hours with $2500 \mathrm{rpm}$ disks rotation keeping a null space between the stone disks (Lavoratti et al., 2016) and were later used for theophylline granules development.

Figure 1. Steps in the process of tobacco stalk lignocellulosic nanofibers suspension obtaining. (a) in natura tobacco stalks; (b) transformation of tobacco stalk into powder form by knife mill; (c) tobacco stalk mechanical fibrillation to produce (d) lignocellulose nanofibers suspensions.

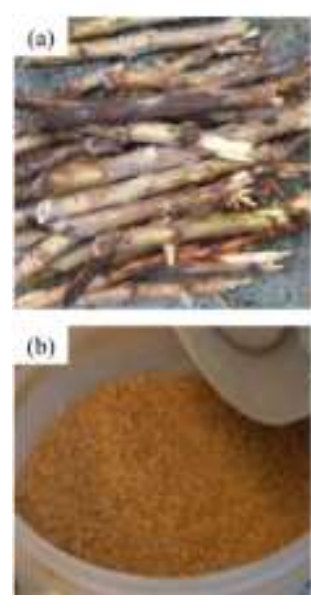

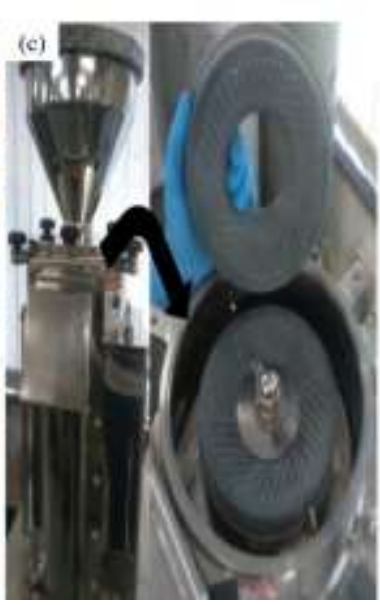

Source: Authors.

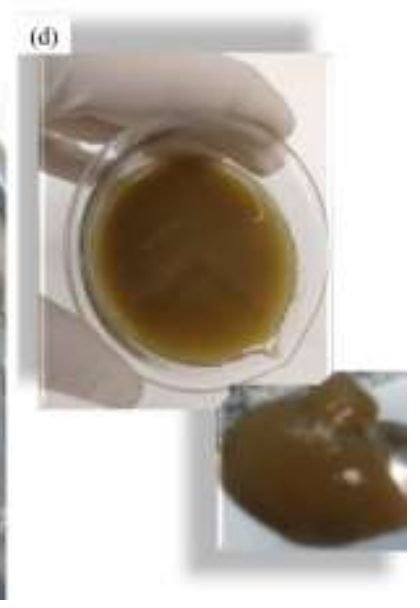

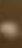




\subsection{Characterization}

\subsubsection{Loss on drying}

The confirmation of the theoretical concentrations obtained in lignocellulosic nanofibers suspensions ( 0.5 and $2.0 \%$, w/v) after the grinding process was carried out in triplicate by determining the loss on drying (USP 42, 2019). Approximately $2 \mathrm{~g}$ of TS-NFC suspensions was transferred to previously calibrated Petry plates. The essay was conducted in a circulating oven (Tecnal, Brazil) at $105^{\circ} \mathrm{C}$ until constant weight. The percentage of loss on drying $(P d)$ was obtained by applying Equation 1:

$$
P d=\frac{P u-P s}{P a} \times 100 \quad \text { (Eq.1) }
$$

where, $P a$ is the sample mass; $P u$ is the mass of the Petry plate containing the sample before drying, and $P s$ is the mass of the Petry plate with sample after drying.

\subsubsection{Determination of lignocellulosic constituents}

After the micronized grinding process (Fig. 1c), samples were assessed according to the Technical Association of Pulp and Paper Industry (TAPPI) standards for: extractives (TAPPI, 1997), ashes and insoluble lignin (TAPPI, 2002). Cellulose content was performed according to National Renewable Energy Laboratory (Determination of Structural Carbohydrates and Lignin in Biomass, 2012) methodology whereas the samples' bleaching was not required. The moisture content was performed at $105^{\circ} \mathrm{C}$ with a Mettler Toledo HB43 (Switzerland) infrared drying unit. Results were compared to raw tobacco stalk powder (Fig. 1b).

\subsubsection{Lignocellulosic suspensions drying and morphological analysis}

Three different drying methods were tested: freeze-drying (FD); spray-drying (SD) and oven-drying (OD) aiming at selecting the technique enabling better fibril visualization.

For FD samples, the lignocellulosic suspensions were dried in a Lio Top, model L-101 Liobrás (Brazil) freeze-dryer equipment at a freezing temperature of $-50^{\circ} \mathrm{C}$ for 24 hours. After that, the samples were transferred separately to a vacuum chamber (Lio Top, model L-101 Liobrás, Brazil) for ice sublimation, using initial vacuum of $500 \mu \mathrm{Hg}$ and final vacuum of $100 \mu \mathrm{Hg}$ (Zanini et al., 2017).

For SD samples, lignocellulosic suspensions were dried in a Büchi mini spray dryer B-290 (Switzerland) in open mode using compressed air and rate of $4 \mathrm{~mL} \cdot \mathrm{min}^{-1}$. The inlet and outlet temperatures were $150^{\circ} \mathrm{C}$ and $89^{\circ} \mathrm{C}$, respectively (Macedo et al., 2017).

The OD samples were dried in a Tecnal (Brazil) oven with air circulation at $105^{\circ} \mathrm{C}$ for $2 \mathrm{~h}$ (Peng et al., 2012). The ideal conditions for time and temperature were $2 \mathrm{~h}$ at $105^{\circ} \mathrm{C}$ for carrying out water evaporation. Water removal was ascertained by sample mass inspection to constant weight.

The morphological analysis was performed after micronized grinding and the three drying methods assayed were analyzed by using a Field Emission Scanning Electron Microscope (FESEM) by Tescan, model Mira 3 (Czech Republic) in order to evidence the presence of lignocellulosic fibers and nanofibers. A small fraction of the dried samples was carefully deposited on a stub containing conductive adhesive tape and covered with gold for 1 minute. The images were obtained at an acceleration voltage of $5.0 \mathrm{kV}$ and fibers diameters were measured by using ImageJ software. 


\subsubsection{Fourier transform infrared (FTIR) spectroscopy}

Fourier transform infrared spectra (FTIR) were obtained using a Nicolet IS10 Thermo Scientific (United States) spectrophotometer. Raw tobacco stalk powder (RTSP) and freeze-dried tobacco stalk lignocellulosic samples were prepared using the $\mathrm{KBr}$ pastille method and scanned in the range from 4000 to $400 \mathrm{~cm}^{-1}$, with spectral resolution of $4 \mathrm{~cm}^{-1}$.

\subsubsection{X-ray diffraction analysis (XRD)}

The cellulose crystallinity of raw tobacco stalk powder (RTSP) and tobacco stalk lignocellulosic nanofibers (TS-NFC) samples was evaluated by X-ray diffraction (XRD) in a Shimadzu XRD-600 (Japan) diffractometer using the following conditions: $\mathrm{Cu} \mathrm{K \alpha}=0.1542 \mathrm{~nm}, 40 \mathrm{kV}, 30 \mathrm{~mA}, 2^{\circ} \leq 2 \theta \leq 50^{\circ}, 0,05^{\circ}, 2 \mathrm{~s}^{-1}$. The crystallinity index was calculated according to the empirical formula (Equation 2) proposed by Segal et al. (1959):

$$
\left.I(\%)=\left(\frac{I_{200}-I_{a m}}{I_{200}}\right) \times 100 \quad \text { (Eq. } 2\right)
$$

where, $I_{200}$ is the peak intensity corresponding to the $(200)$ plane at the diffraction angle of $2 \theta=22.5^{\circ}$ and $I_{a m}$ the valley intensity between the $\left(\begin{array}{lll}2 & 0 & 0\end{array}\right)$ and $\left(\begin{array}{lll}1 & 1 & 0\end{array}\right)$ planes at the diffraction angle of $2 \theta=18^{\circ}$.

\subsubsection{Thermal analysis}

The analysis by differential scanning calorimetry (DSC) for raw tobacco stalk powder (RTSP) and TS-NFC samples was carried out in a Shimadzu DSC-50 (Japan) equipment using a heating rate of $10^{\circ} \mathrm{C} . \mathrm{min}^{-1}$ under nitrogen atmosphere at a rate of $50 \mathrm{~mL} \cdot \mathrm{min}^{-1}$ from $25^{\circ} \mathrm{C}$ to $270^{\circ} \mathrm{C}$. The values were obtained from the curves generated in the first heating and cooling run.

Thermogravimetry (TGA) was performed in a Shimadzu TGA-50 (Japan) equipment under nitrogen atmosphere at a rate of $50 \mathrm{~mL} \cdot \mathrm{min}^{-1}$. The heating rate was $10^{\circ} \mathrm{C} \cdot \mathrm{min}^{-1}$ at a temperature range from $23^{\circ} \mathrm{C}$ to $800^{\circ} \mathrm{C}$. The sample mass was approximately $10 \mathrm{mg}$.

\section{Results and Discussion}

\subsection{Nicotine determination in tobacco stalks}

\subsection{1 ${ }^{1} \mathrm{H}$ NMR}

The ${ }^{1} \mathrm{H}$ NMR spectra of raw tobacco stalk powder (RTSP) and pretreated tobacco stalk lignocellulosic nanofiber (TS-NFC) are shown in Figure 2(a). 
Figure 2. (a) 1H NMR spectra showing the chemical shifts for (i) raw tobacco stalk powder (RTSP) and (ii) pre-treated tobacco stalk lignocellulosic nanofibers and (b) tobacco stalk thin layer chromatography being (i) raw tobacco stalk powder; (ii) tobacco leaves powder; (iii) cigarette blend; (iv) nicotine standard.

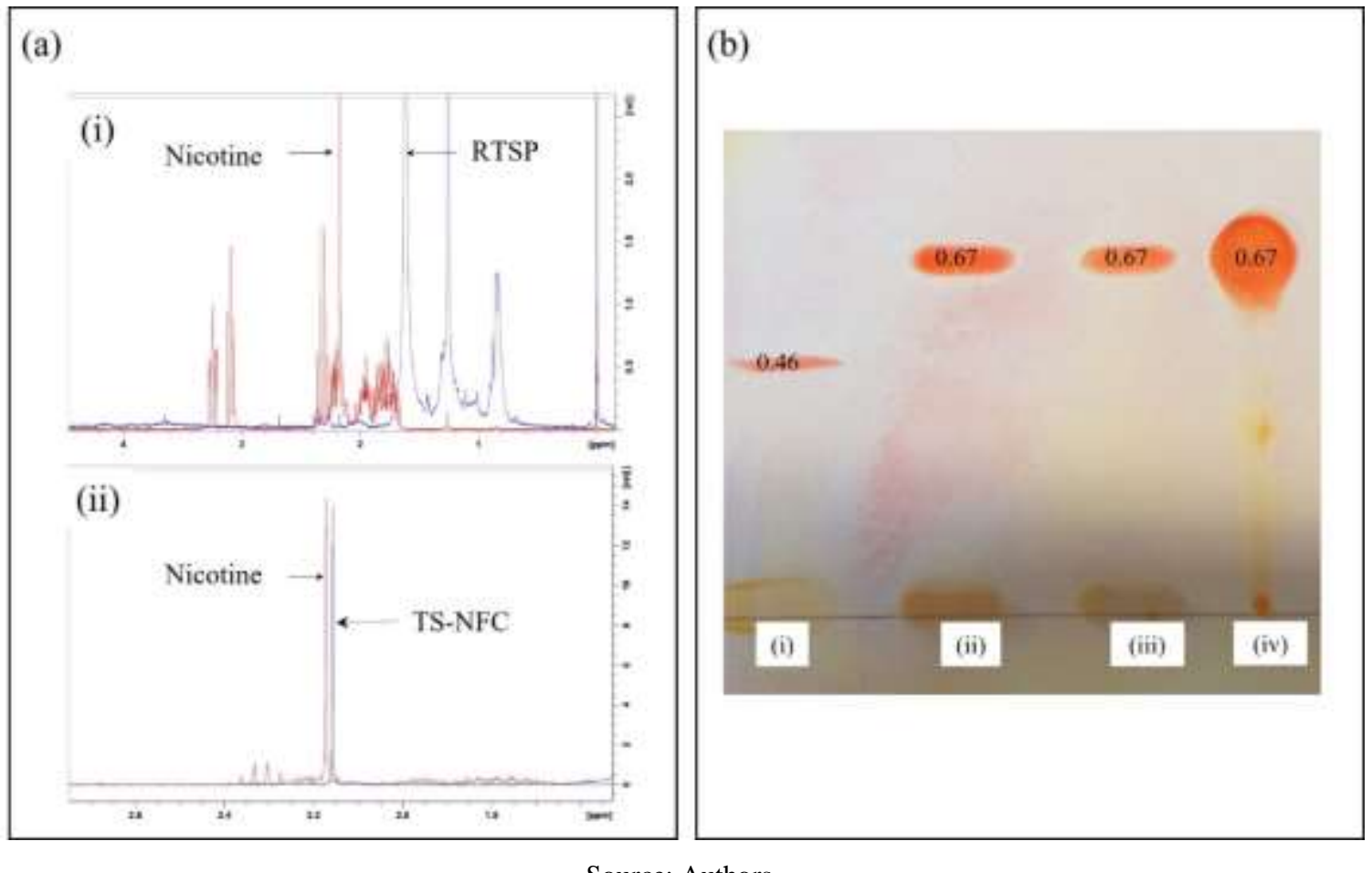

Based on nicotine standard, it was possible to evidence all chemical shifts according to data shown in the literature (Hosu \& Cimpoiu, 2015; James F. Pankow et al., 2002). ${ }^{1} \mathrm{H}$ NMR (300 Hz, $\left.\mathrm{CDCl}_{3}\right) \delta 8.54(\mathrm{~s}, 1 \mathrm{H}), 8.48$ (d, J= 5.0, $\left.1.5 \mathrm{~Hz}, 1 \mathrm{H}\right)$, $7.68(\mathrm{~d}, 1 \mathrm{H}), 7.24(\mathrm{dd}, \mathrm{J}=8.0,5.0 \mathrm{~Hz}, 1 \mathrm{H}), 3.24(\mathrm{t}, \mathrm{J}=7.5 \mathrm{~Hz}, 1 \mathrm{H}), 3.09(\mathrm{t}, \mathrm{J}=8.5 \mathrm{~Hz}, 1 \mathrm{H}), 2.36-2.27(\mathrm{~m}, 1 \mathrm{H}), 2.17(\mathrm{~s}, 3 \mathrm{H})$. Therefore, the expected signals related to the nicotine molecule in nicotine standard could be obtained. Hydrogens 1 to 4 on nicotine molecular structure refer to the aliphatic chain while hydrogens 7 to 9 relate to signals corresponding to pyridine hydrogens.

As expected for RTSP and TS-NFC, neither sample had shown the presence of nicotine in its composition. The signals collected for RTSP ${ }^{1} \mathrm{H}$ NMR $\left(300 \mathrm{~Hz}, \mathrm{CDCl}_{3}\right)$ were $\delta 7.26\left(\mathrm{~s}, \mathrm{CDCl}_{3}\right), 1.61(\mathrm{~s}, \mathrm{~J}=5.0,1.5 \mathrm{~Hz})$. The signals obtained for TS-NFC, were ${ }^{1} \mathrm{H}$ NMR $\left(300 \mathrm{~Hz}, \mathrm{CDCl}_{3}\right) \delta 7.25\left(\mathrm{~s}, \mathrm{CDCl}_{3}\right), 2.15(\mathrm{~s}, \mathrm{~J}=5.0,1.5 \mathrm{~Hz})$.

In nicotine standard, the corresponding chemical shift occurs at $2.17 \mathrm{ppm}$ and for the RTSP sample; there was no peak nearby the nicotine standard signal. For TS-NFC sample the chemical shift was very close, at 2.15 ppm, to the one obtained for the nicotine standard. Although numerically the values are close, it is not possible to assure that 2.15 ppm refers to the same substance, since the peaks do not overlap.

Therefore, the absence of nicotine in the composition of tobacco stalk nanofibrillated cellulose (TS-NFC) sample and in tobacco stalk in natural form can be strongly demonstrated.

\subsubsection{Thin layer chromatography}

Chromatographic plate obtained by TLC on (i) raw tobacco stalk powder, (ii) tobacco leaves powder, and (iii) cigarette blend comparing with (iv) nicotine standard is presented in Figure 2(b). Thus, for certain identification of nicotine, the plate was sprayed with a specific color Dragendorff's reagent. This reagent usually forms an orange-red colored complex in the reaction 
with alkaloids. Consequently, the characteristic zone of nicotine appears as orange bands on a yellow background of derivatized chromatographic plate (Hosu \& Cimpoiu, 2015).

The intensity of the bands separated on the chromatographic plate seem to be different in distinct samples. Raw tobacco stalk powder (i) showed an alkaloid presence at Rf 0.46 while nicotine standard (iv) presented the nicotine band at Rf 0.67 which indicates the presence of different alkaloids, which may be attributed to nicotine derivatives such as nornicotine or anabasine (Wagner \& Bladt, 1996).

\subsection{Characterization}

\subsubsection{Loss on drying}

Results of real concentration of tobacco stalk lignocellulosic nanofibers suspensions are shown in Table 1 and as expected, solid proportion corresponds to theoretical concentration.

Table 1. Real concentrations of tobacco stalk lignocellulosic nanofibers suspensions.

\begin{tabular}{lcc}
\hline Sample & Theoretical concentration & Real concentration \\
& $(\boldsymbol{\%})$ & $0.57 \pm 0.03$ \\
\hline Tobacco stalk lignocellulosic nanofibers & 0.5 & $2.26 \pm 0.32$ \\
suspensions & 2.0 & $\mathbf{\%})$ \\
\hline
\end{tabular}

Results are expressed as mean \pm standard deviation $(n=3)$. Source: Authors.

\subsubsection{Determination of lignocellulosic constituents}

Table 2 shows the characterization of tobacco stalk lignocellulosic nanofibers (TS-NFC) compared to its natural form (RTSP).

Table 2. Chemical characterization of raw tobacco stalk powder versus tobacco stalk lignocellulosic nanofibers.

\begin{tabular}{lcc}
\hline \multicolumn{1}{c}{$\begin{array}{c}\text { Constituents } \\
(\boldsymbol{\%}, \mathbf{w} / \mathbf{w})\end{array}$} & RTSP & TS-NFC $^{\text {a }}$ \\
\hline$\alpha$-cellulose & $32.4 \pm 1.3$ & $29.2 \pm 0.7$ \\
Hemicellulose & $11.0 \pm 0.5$ & $10.0 \pm 0.8$ \\
Insoluble lignin & $22.1 \pm 3.5$ & $20.1 \pm 0.2$ \\
Extractives & $10.7 \pm 1.0$ & $0.00 \pm 0.0$ \\
Ashes & $4.8 \pm 1.0$ & $2.6 \pm 0.05$ \\
Moisture content & $6.6 \pm 0.6$ & $6.3 \pm 0.00$ \\
\hline
\end{tabular}

RTSP: Raw Tobacco Stalk Powder; TS-NFC: Tobacco Stalk Lignocellulosic Nanofibers; ${ }^{2}$ Extractive free basis. Results are expressed as mean \pm standard deviation $(\mathrm{n}=3)$. Source: Authors.

Extractives free basis concentration of insoluble lignin $(20.1 \pm 0.2 \%)$ was higher than the value presented by Agrupis and Maekawa (1999), 17.3\%. Due to the composition of tobacco stalk being mainly starch, pectin and compounds that give tobacco's color and flavor (Shakhes et al., 2011), it was necessary to determine the extractives content. The removal of extractives might have influenced the ash content when compared with raw tobacco stalk.

It was not possible to completely remove lignin in TS-NFC samples, which is present in lower amount as compared with RTSP. As a result, the materials cannot be considered as cellulose, but instead, lignocellulose, since some non-cellulosic material is still present in the fiber composition. 
The literature shows some differences related to $\alpha$-cellulose content in which the results may vary due to the tobacco species and stalk portion according to plant height (Soni et al., 2015). According to Agrupis et al. (2000) and Shakhes et al. (2011), tobacco stalk contains from 35 to 40\% of cellulose. In a study reported by Kulić and Radojičić (2011), the content of $\alpha$-cellulose in Virginia species tobacco stalk was 30.5\%. In the study conducted by Agrupis \& Maekawa (1999) on the same tobacco stalk species, the $\alpha$-cellulose content found was 33.9\%. Tuzzin et al. (2016) reported $\alpha$-cellulose content for tobacco stem (midrib) on an extractives free base as being $41.75 \%$ while in the raw tobacco stem sample the content was $20.85 \%$. The results reported by the above-mentioned authors supported and confirmed those obtained for the evaluated compositions with and without pretreatment.

\subsubsection{Lignocellulosic suspensions drying and morphological analysis}

Three drying methods were assayed: freeze-drying (FD), spray-drying (SD) and oven-drying (OD) and the micrographs are shown in Figure 3.

Figure 3. FESEM micrographs of dried tobacco stalk lignocellulosic nanofibers (TS-NFC) at 0.5 and $2.0 \%$ (w/v). Freeze-dried tobacco stalk lignocellulosic nanofibers at 50,000x magnification (a) at 0.5\% (w/v); (b) at 2.0\% (w/v). Spray-dried tobacco stalk lignocellulosic nanofibers at 30,000x magnification (c) at $0.5 \%(\mathrm{w} / \mathrm{v}) ;(\mathrm{d})$ at $2.0 \%(\mathrm{w} / \mathrm{v})$. Oven-dried tobacco stalk lignocellulosic nanofibers at 1,000x magnification (e) at $0.5 \%(\mathrm{w} / \mathrm{v})$ and (f) at $2.0 \%(\mathrm{w} / \mathrm{v})$.

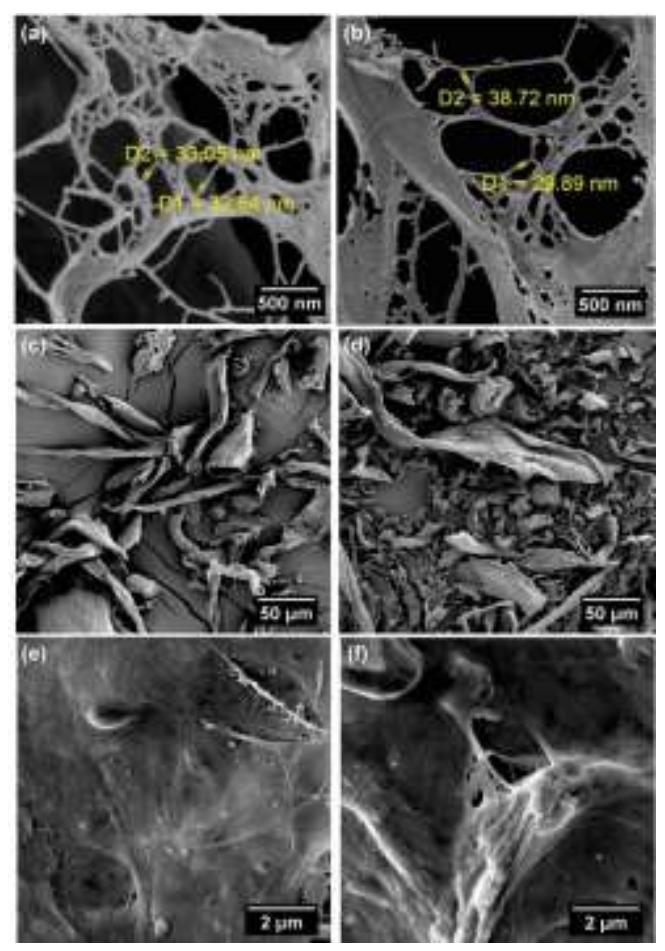

Source: Authors.

All samples are agglomerated and difficult to observe individual lignocellulosic nanofiber however, among the tested drying methods, visualization was facilitated by freeze-drying (FD) tobacco stalk lignocellulosic nanofibers (Fig. 3a-b). Fibrils were more preserved than the others applied techniques and shown certain individualization, despite the agglomeration, relative to the other techniques applied at both concentrations tested, 0.5 and $2.0 \%$, w/v. Despite fiber agglomeration, it was possible to measure the diameter of some fibrils, as shown in Fig. 3(a-b), in which they appeared to be in the nanometric range. At the lower 
concentration (Fig. 3a), the sample mean diameter was $32.8 \mathrm{~nm}$ and for the higher concentration (Fig. 3b), the mean diameter was $34.3 \mathrm{~nm}$ among the measured fibrils.

According to Trache et al. (2017) and Brinchi et al. (2013), freeze-drying and supercritical drying are capable of create highly networked structures of agglomerates with multi-scalar dimensions including nanoscale. In the present study, the FD method was able to dry tobacco stalk lignocellulosic nanofibers (TS-NFC) fibrils for both concentrations used and kept them partially individualized. Among the available techniques, FD seems to be a low-cost, simple and versatile route for lignocellulosic nanofibers obtainment. During an aqueous suspension FD process, suspended particles are organized in the space between growing ice crystals, forming a crystalline structure after ice crystals sublimation (Han et al., 2013)

Spray-drying (SD), Fig. 4(c-d), was not the best technique to obtain nanocellulose from cellulosic fiber, once it may have caused fiber agglomeration and fiber dimension were kept in the micrometric scale. This situation was observed for both concentrations, 0.5 and 2.0\%. Peng et al. (2012) described that a disadvantage of SD is that agglomeration can occur, and the particles size range from nano to micron size. Zimmermann et al. (2016) reported that the size and type of nanocellulose (nanocrystals or nanofibers) in the suspension also affect the final size of the dried product. Agglomeration tends to appear more easily in nanofibrillated cellulose (NFC) than in cellulose nanocrystals (CNC) and, thus, larger droplets are formed during spraying. For this reason, SD has been suggested as a technically suitable production procedure for drying lignocellulosic nanofibers suspensions (Brinchi et al., 2013; Trache et al., 2017). The larger the lignocellulosic nanofibers droplets, the larger the dried fibrils and the greater the particles irregularity (Zimmermann et al., 2016). In spite of this drawback, it is an important method to obtain cellulose nanocrystals (CNC) (Abdul Khalil et al., 2014; Han et al., 2013; Peng et al., 2012; Zimmermann et al., 2016).

Fiber agglomeration was also observed in oven-dried (OD) tobacco stalk lignocellulosic nanofibers (Fig. 4 e-f), making them a unified single surface which did not allow to distinguish fibers and, because of this, the presence of nanocellulose was not evidenced. Oven-dried samples showed a rough and unified surface that made it not possible to distinguish fibrils individualization. The loss of nanoscale dimension is a common disadvantage in OD. This could have happened since the distance between lignocellulosic nanofibrils became smaller, promoting molecular contact by capillary effect and diffusion forces. This situation may favor strong intermolecular hydrogen bond formation promoting a continuous fiber network and a bulk network structure (Zimmermann et al., 2016). This technique was used as lignocellulosic nanofibers negative control.

The difference among drying methods was explained by Peng et al. (2012) and Han et al. (2013) as being due to hydrogen bonds and van der Waals forces that keep fibrils united after water removal and then forming agglomerates. Nanocellulose obtainment is complete according to the drying method chosen (Brinchi et al., 2013), where water removal becomes a delicate process, being determinant to keep fibrils in the nanoscale range (Peng et al., 2012).

Different drying methods are efficient in terms of avoiding agglomeration (Peng et al., 2012, 2013), such as for example, supercritical drying. However, this technique requires several solvent exchange steps, besides requiring huge amounts of solvents in the drying step. Nonetheless, the non-agglomeration of nanofibers depends on the drying method and the kind of raw material, among other features.

After lignocellulosic biomass manufacturing, an evenly dispersed lignocellulosic nanofibers aqueous suspension as a colloidal system was obtained. The hydroxyls present in cellulose structure form strong hydrogen bonds between cellulose and water molecules, keeping the system stable (Brinchi et al., 2013; Peng et al., 2012).

\subsubsection{Fourier transform infrared (FTIR) spectroscopy}

FTIR spectra for RTSP, TS-NFC-05 and TS-NFC-2 samples are shown in Figure 4(a). 
Figure 4. (a) FTIR spectra showing bands and their respective cellulosic samples functional groups and (b) X-ray diffractogram of tobacco stalk lignocellulosic nanofibers after $5 \mathrm{~h}$ grinding comparing with tobacco stalk cellulose in its natural form.
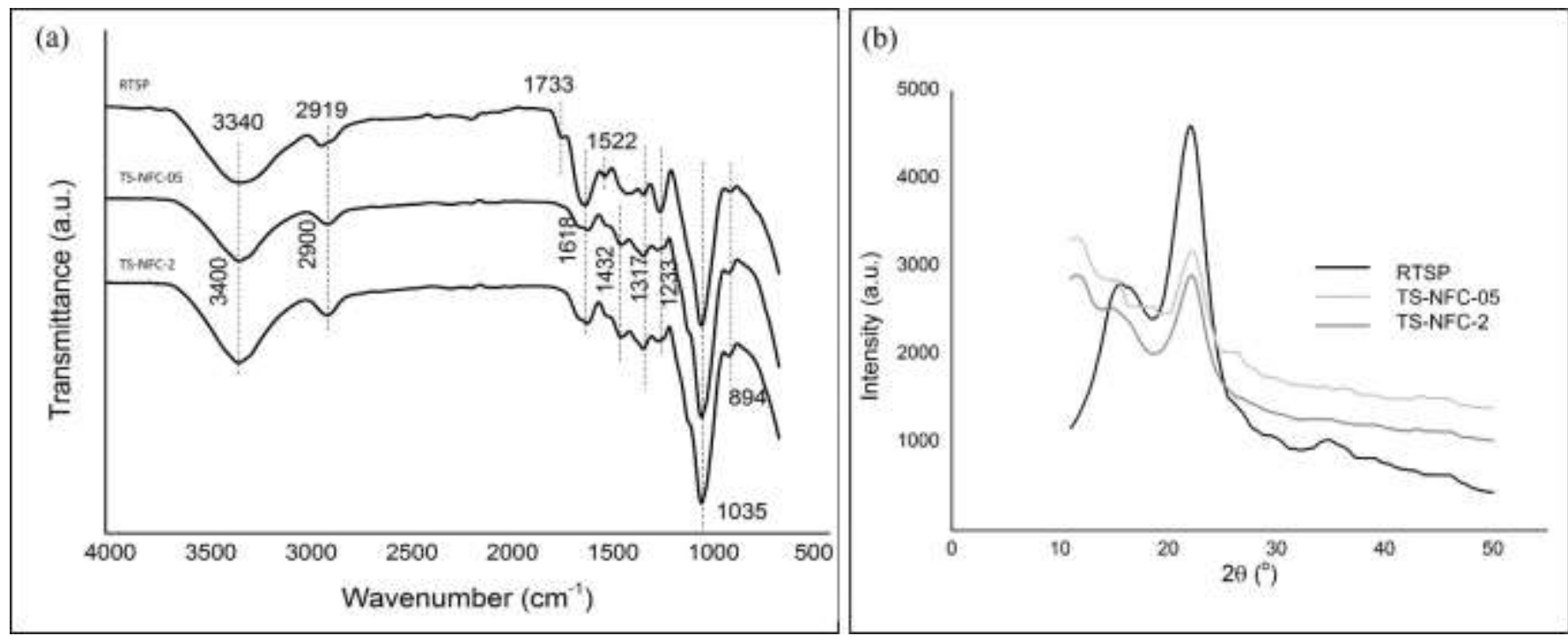

Source: Authors.

The broad band between $3400-3340 \mathrm{~cm}^{-1}$ was assigned to the stretching vibration of the O-H bonding of cellulose and absorbed water (Lavoratti et al., 2016). An interesting characteristic observed was the different bands width of the three samples at $3400-3340 \mathrm{~cm}^{-1}$. In RTSP the band is wider and may be related to the associated O-H bond due to agglomeration, whereas in TS-NFC-05 and TS-NFC-2 spectra the band is thinner and possibly may be related to the free O-H bond due to nanofibril formation. In a study performed by Han et al. (2013) on wood nanocellulose, their samples presented narrow bands in the $3442 \mathrm{~cm}^{-1}$ region, these being assigned to intramolecular hydrogen bonding in cellulose II, which confirms the result found for mercerized tobacco stalk lignocellulosic nanofibers. There is a thorough discussion about intra- and inter- molecular $\mathrm{H}-$ bonds in cellulose I, II and lignin, which is very well explained elsewhere (Poletto et al., 2012a).

Between $2919-2900 \mathrm{~cm}^{-1}$ the absorption band was attributed to the stretching vibration of the $\mathrm{C}-\mathrm{H}$ bonding of cellulose (Ashori et al., 2014; Gómez-Siurana et al., 2013).

Unlike TS-NFC-05 and TS-NFC-2, RTSP exhibits an absorption band at $1733 \mathrm{~cm}^{-1}$ which is attributed to the acetyl group of hemicelluloses uronic ester or to the carboxylic ester group of the ferulic ring and p-coumaric acid (Maafi et al., 2010; Trache et al., 2014), while its absence in TS-NFC-05 and TS-NFC-2 indicates the successful removal of hemicelluloses during the mercerization treatment (Haafiz et al., 2016). The band at $1618 \mathrm{~cm}^{-1}$ was present in all the three samples and is related to the bending of absorbed water (Kalita et al., 2013).

For lignocellulosic nanofiber samples, the bands around $1432 \mathrm{~cm}^{-1}$ were attributed to the $\mathrm{CH}_{2}$ bending vibration (Ouajai et al., 2004). This band is also known as the crystallinity band and an increase in its intensity demonstrates higher degree of crystallinity (Kalita et al., 2013). The band at $1522 \mathrm{~cm}^{-1}$ is assigned as the $\mathrm{C}=\mathrm{C}$ stretching of the lignin aromatic ring (Haafiz et al., 2016; Rosa et al., 2012), since some non-cellulosic material is still present in the fiber composition thus, this observation demonstrates that the micronized mill grinding process was efficient to obtain lignocellulosic nanostructures and that the pretreatment process was able to partially remove lignin, this being based on the presence of an absorbance band at the region around $1500 \mathrm{~cm}^{-1}$ on TS-NFC-05 and TS-NFC-2 samples. 
The other bands appeared in all samples. The band at $1317 \mathrm{~cm}^{-1}$ was related to $\mathrm{CH}_{2}$ wagging (Chen et al., 2015; Soni et al., 2015). The band at $1233 \mathrm{~cm}^{-1}$ was assigned as $\mathrm{C}-\mathrm{OH}$ bending in the plane at $\mathrm{C} 6$ (Han et al., 2013).

At $1035 \mathrm{~cm}^{-1}$, the band was attributed to the $\mathrm{C}-\mathrm{O}$ deformation at $\mathrm{C} 6$ in cellulose (Soni et al., 2015), and finally at $894 \mathrm{~cm}^{-1}$ the absorption band was attributed to the $\beta$-glycosidic linkages of cellulose glucose ring (Chen et al., 2015; Kaushik \& Singh, 2011; Rosa et al., 2012).

\subsubsection{X-ray diffraction analysis}

X-ray diffraction analyses were performed, and the crystallinity index of tobacco stalk lignocellulosic nanofibers was calculated. Figure 4(b) shows the diffractogram of raw tobacco stalk powder (RTSP) and tobacco stalk lignocellulosic nanofibers (TS-NFC-05 and TS-NFC-2) samples.

The biomasses evaluated show values of $22.08^{\circ}$ for the $\left(\begin{array}{lll}2 & 0 & 0\end{array}\right)$ planes. Native cellulose (cellulose I) diffraction peaks appeared at $14.67^{\circ}$ and $22.53^{\circ}$ for the $\left(\begin{array}{lll}1 & 1 & 0\end{array}\right)$ and $\left(\begin{array}{lll}2 & 0 & 0\end{array}\right)$ planes (Klemm et al., 2005). For cellulose II the diffraction peaks generally appear at $12.1^{\circ}$ and $22.0^{\circ}$ for the $\left(\begin{array}{lll}1 & 1 & 0\end{array}\right)$ and $\left(\begin{array}{lll}2 & 0 & 0\end{array}\right)$ planes. The XRD of TS-NFC-05 and TS-NFC-2 shows the patterns of crystalline native cellulose I with non-existing cellulose II, indicated by the absence of a doublet located at $22^{\circ}$ (Haafiz et al., 2016; Rosa et al., 2012).

By applying the equation shown in section 2.5.5, the samples crystallinity index data were summarized in Table 3 .

Table 3. Crystallinity of TS-NFC-05 and TS-NFC-2 compared to the original fibers (RTSP).

\begin{tabular}{cc}
\hline Sample & Crystallinity \\
& $(\boldsymbol{\%})$ \\
\hline RTSP & 46.7 \\
TS-NFC-05 & 35.4 \\
TS-NFC-2 & 42.2 \\
\hline
\end{tabular}

RTSP: raw tobacco stalk powder; TS-NFC-05: tobacco stalk lignocellulosic nanofibers at $0.5 \%(\mathrm{w} / \mathrm{v})$; TS-NFC-2: tobacco stalk lignocellulosic nanofibers at $2.0 \%(\mathrm{w} / \mathrm{v})$. Source: Authors.

The crystallinity of RTSP was higher than the other two samples since this one was used in pure form, that is, without any sample treatment. The aim of this analysis was precisely to compare the results between the non-treated, non-processed sample with the treated, processed samples, hence the difference in crystallinity.

Lignocellulosic nanofibers' crystallinity of both cases, TS-NFC-05 and TS-NFC-2, was lower than the original fibers (RSTP) meaning that in lignocellulosic materials, only cellulose exhibits a crystalline structure, whereas hemicelluloses and lignin are amorphous (Poletto et al., 2012b).

The lower crystallinity index of TS-NFC-05 can also have occurred because of the mercerization treatment applied to samples in which random cellulose cleavage can occur in accessible chains with crystalline domains, contributing to the amorphous character increase (Klemm et al., 2005). The significant drop of crystallinity index and the earlier treatment with $\mathrm{NaOH}$ of tobacco stalk cellulose were indicative of lower alkalinity resistance compared with raw tobacco stalk powder (RTSP) (Ouajai et al., 2004).

Similar decrease of crystallinity was observed by Iwamoto et al., (2007); Lavoratti et al., (2016); Lengowski et al., (2013); and Tuzzin et al. (2016) where these authors used the micronized mill. The authors reported lignocellulosic nanofibers 
production by applying mechanical processes. Notwithstanding, the mentioned process can frequently cause lignocellulosic fibers crystalline parts to break down leading to rise in the amount of amorphous structures.

Despite the lower crystallinity index, by carefully studying Figure 4(b), it was possible to notice that TS-NFC-05 and TS-NFC-2 diffractograms had lower peaks when compared with RTSP, which is a characteristic of the presence of nanostructures, and for this reason, it was possible to consider the samples after micronized mill grinding as lignocellulosic nanofibers.

\subsubsection{Thermal analysis}

The thermogravimetric curves for tobacco stalk lignocellulosic nanofibers after grinding are shown in Figure 5.

Figure 5. (a) DSC curves and (b) TGA-DTG curves for tobacco stalk lignocellulosic nanofibers at both evaluated concentrations $(0.5$ and $2.0 \%, \mathrm{~m} / \mathrm{v}$ ) compared with raw tobacco stalk powder (RTSP).
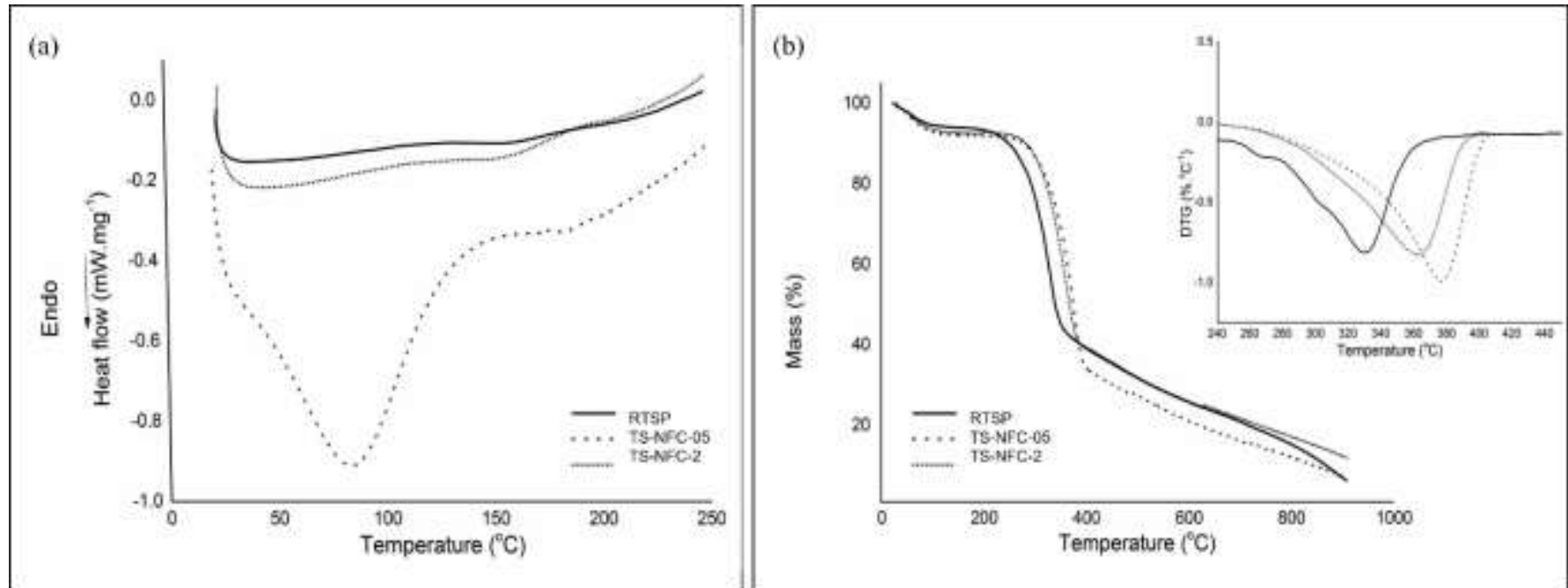

Source: Authors.

Figure 5(a) shows the DSC curves for tobacco stalk lignocellulosic nanofibers at the evaluated concentrations of 0.5 and $2.0 \%, \mathrm{w} / \mathrm{v}$. DSC was used in materials characterization, specifically to characterize lignocellulosic nanofibers, since it enables prediction of material's thermal stability, this information being relevant for the design and material application step.

The first characteristic noticed in the curves was the difference between samples TS-NFC-05 and TS-NFC-2. This was probably due to concentration difference, since TS-NFC-2 is more concentrated and, therefore, more similar to RTSP. Besides, sample concentration submitted to grinder stones can influence the result. Moreover, fiber size is also a factor that can influence the properties of cellulosic material (Dinh Vu et al., 2017).

The TS-NFC-2 and RTSP curves show a weight loss event under $50^{\circ} \mathrm{C}$, referring to cellulose moisture vaporization (Ramiah, 1970). There is a small event at around $160^{\circ} \mathrm{C}$ that shifted to $165^{\circ} \mathrm{C}$ for TS-NFC-2 and RTSP. This was probably due to hemicelluloses content, more specifically, xylan content, which is responsible for curve smoothing (Lengowski et al., 2013). This result can be confirmed by FTIR results presented at section 3.2.4. It is unlikely that the slight endothermic shoulder at $170^{\circ} \mathrm{C}$ corresponds to a xylan dehydration process since this phenomenon involves a primary $\mathrm{OH}$ group and xylan does not have any primary $\mathrm{OH}$ groups as does cellulose. However, this temperature could correspond to xylan softening (Chen et al., 2015).

For TS-NFC-05 curves, a weight loss event at $75^{\circ} \mathrm{C}$ related to moisture (Ramiah, 1970) was observed. Over $180^{\circ} \mathrm{C}$, cellulose degradation begins, which is a consequence of cellulose dehydration and depolymerization, leading to formation of 
volatile products. Approximately between $200-300^{\circ} \mathrm{C}$ heat flow becomes linear and crescent which could be indicative of lignin thermal degradation (Shen et al., 2010).

Thermogravimetric analysis was performed in order to characterize tobacco stalk lignocellulosic nanofibers thermal behavior for untreated and treated samples. To RSTP three main weight loss events were observed in Figure 5(b), in which the event at $60^{\circ} \mathrm{C}$ is associated to water evaporation (5.6\% loss) (Trache et al., 2014). At $341^{\circ} \mathrm{C}$, the event is related to cellulose dehydration followed by thermal depolymerization; and at $368^{\circ} \mathrm{C}$ the event is referred to cellulose thermal decomposition into D-glucopyranose monomers (Ashori et al., 2014; Trache et al., 2014). For TS-NFC-05 and TS-NFC-2, the events were the same but shifted relative to the tobacco sample in its natural form.

Figure 5(b) depicts the TGA-DTG curves for RTSP where it was possible to observe a maximum for cellulose degradation at $327^{\circ} \mathrm{C}$. To the processed samples TS-NFC-05 and TS-NFC-2, the maxima occurred at $376^{\circ} \mathrm{C}$ and $363^{\circ} \mathrm{C}$, respectively. DTG observed peak refer to the second TGA event. Table 4 shows the main weight loss events and maximum degradation temperatures $\left(T_{\max }\right)$ of samples.

Table 4. Main weight loss events and maximum degradation temperatures $\left(T_{\max }\right)$ of tobacco stalk samples.

\begin{tabular}{|c|c|c|c|c|c|c|}
\hline \multirow[b]{2}{*}{ Samples } & \multicolumn{2}{|c|}{ First event } & \multicolumn{2}{|c|}{ Second event } & \multirow{2}{*}{$\begin{array}{c}\text { Third event } \\
\text { Weight loss } \\
(\%)\end{array}$} & \multirow[b]{2}{*}{$\begin{array}{c}\text { Residual char } \\
\text { (\%) }\end{array}$} \\
\hline & $\begin{array}{l}\mathbf{T}_{\max } \\
\left({ }^{\circ} \mathbf{C}\right)\end{array}$ & Weight loss (\%) & $\begin{array}{l}\mathbf{T}_{\max } \\
\left({ }^{\circ} \mathbf{C}\right)\end{array}$ & $\begin{array}{c}\text { Weight loss } \\
(\%)\end{array}$ & & \\
\hline RTSP & 60.0 & 5.6 & 327 & 44.3 & 22.1 & 48.0 \\
\hline TS-NFC-05 & 55.2 & 7.0 & 376 & 54.2 & 29.4 & 9.4 \\
\hline TS-NFC-2 & 59.7 & 6.7 & 363 & 52.7 & 28.3 & 12.3 \\
\hline
\end{tabular}

RTSP: raw tobacco stalk powder; TS-NFC-05: tobacco stalk lignocellulosic nanofibers at $0.5 \%$ (w/v); TS-NFC-2: tobacco stalk lignocellulosic nanofibers at $2.0 \%(\mathrm{w} / \mathrm{v})$. Source: Authors.

This result corresponds to that mentioned by Tuzzin et al. (2016) in which the maximum thermal degradation peak was around $360^{\circ} \mathrm{C}$. The difference observed between raw material and treated material is probably due to cellulose regeneration process that starts by the mercerization process (Li Xiaoping, Wu Zhangkang, 2014) leading to sample crystallinity index reduction in alkaline medium resulting from fibers swelling. In this case, $\mathrm{pH}$ neutralization in an acidic medium indicates cellulose restructuration and higher thermal stability (Kaushik \& Singh, 2011).

Since cellulose thermal degradation is influenced by its composition and crystallinity (Poletto et al., 2012b), the agglomeration of cellulose fibrils might provide an opportunity to increase the tobacco stalk lignocellulosic crystallinity index. For higher concentrations of cellulose solutions, hydrogen bonding can occur directly among cellulose chains hydroxyl groups. Hydrogen-bonding drives nanocellulose fibrils to approach each other more closely and form tight aggregates resulting in crystalline structures formation (Peng et al., 2013).

\section{Conclusion}

Every effort for environmental preserve requires an in-depth study and evaluation of new materials, especially when it is intended to apply to health. Giving an unusual destination of an agricultural waste as it is the tobacco stalk and transform it in a potential novel excipient for pharmaceutical application seemed to succeed throughout the performance of the present work. The assays conducted in tobacco stalk samples permitted to conclude for the absence of nicotine in the examined samples. The grinding process was successful for obtaining lignocellulosic nanofibers (LNF) showing that the material concentration influenced the diameter of freeze-dried fibers. Measurements for the elucidation of lignocellulosic nanofibers were more efficient 
when XRD and FESEM were conducted whereby LNF exhibited an approximate diameter of $30 \mathrm{~nm}$ for both tested concentrations. Nanofibers from TS-NFC-05 had lower crystallinity and higher thermal stability, which can be attributed to the lower fiber dimension in comparison with TS-NFC-2. The characterization techniques applied permit to evaluate the tobacco's stalk biomass and expand its application field to pharmaceutics as a valuable excipient for drug development. Therefore, further studies comprising the development of solid dosage forms applying lignocellulosic nanofibers are required, as well in vivo safety in order to determine its promising use as excipient.

\section{Acknowledgments}

The authors would like to thank to Laboratório de Microbiologia Aplicada (UCS) for carrying out the freeze-drying method, to Laboratório Central de Microscopia Professor Israel Baumvol (UCS) for field emission scanning electron microscopy, to Professor Dr. Thiago Barcellos da Silva for running the ${ }^{1} \mathrm{H}$ NMR and to the Faculty of Pharmacy of the Federal University of Rio Grande do Sul (UFRGS). This study was financed in part by Coordenação de Aperfeiçoamento de Pessoal de Nível Superior - Brasil (CAPES) - Finance Code 001.

\section{References}

Abdul Khalil, H. P. S., Davoudpour, Y., Islam, Md. N., Mustapha, A., Sudesh, K., Dungani, R., \& Jawaid, M. (2014). Production and modification of nanofibrillated cellulose using various mechanical processes: A review. Carbohydrate Polymers, 99, 649-665. https://doi.org/https://doi.org/10.1016/j.carbpol.2013.08.069

Agrupis, S. C., \& Maekawa, E. (1999). Industrial Utilization of Tobacco Stalks (1) Preliminary Evaluation for Biomass Resources. Holzforschung, 53(1), 2932. https://doi.org/10.1515/HF.1999.005

Agrupis, S., Maekawa, E., \& Suzuki, K. (2000). Industrial utilization of tobacco stalks II: preparation and characterization of tobacco pulp by steam explosion pulping. Journal of Wood Science, 46(3), 222-229. https://doi.org/10.1007/BF00776453

Akpinar, O., Erdogan, K., Bakir, U., \& Yilmaz, L. (2010). Comparison of acid and enzymatic hydrolysis of tobacco stalk xylan for preparation of xylooligosaccharides. LWT - Food Science and Technology, 43(1), 119-125. https://doi.org/10.1016/J.LWT.2009.06.025

Ashori, A., Babaee, M., Jonoobi, M., \& Hamzeh, Y. (2014). Solvent-free acetylation of cellulose nanofibers for improving compatibility and dispersion. Carbohydrate Polymers, 102, 369-375. https://doi.org/10.1016/J.CARBPOL.2013.11.067

Berger, S., \& Sicker, D. (2009). Alkaloids. In Classics in spectroscopy : isolation and structure elucidation of natural products (First edition, pp. 1-128). Wiley$\mathrm{VCH}$.

Brinchi, L., Cotana, F., Fortunati, E., \& Kenny, J. M. (2013). Production of nanocrystalline cellulose from lignocellulosic biomass: Technology and applications. Carbohydrate Polymers, 94(1), 154-169. https://doi.org/https://doi.org/10.1016/j.carbpol.2013.01.033

Carlsson, D. O., Hua, K., Forsgren, J., \& Mihranyan, A. (2014). Aspirin degradation in surface-charged TEMPO-oxidized mesoporous crystalline nanocellulose. International Journal of Pharmaceutics, 461(1-2), 74-81. https://doi.org/10.1016/J.IJPHARM.2013.11.032

Chen, Z., Hu, T. Q., Jang, H. F., \& Grant, E. (2015). Modification of xylan in alkaline treated bleached hardwood kraft pulps as classified by attenuated totalinternal-reflection (ATR) FTIR spectroscopy. Carbohydrate Polymers, 127, 418-426. https://doi.org/10.1016/J.CARBPOL.2015.03.084

Cherian, B. M., Leão, A. L., de Souza, S. F., Thomas, S., Pothan, L. A., \& Kottaisamy, M. (2010). Isolation of nanocellulose from pineapple leaf fibres by steam explosion. Carbohydrate Polymers, 81(3), 720-725. https://doi.org/10.1016/J.CARBPOL.2010.03.046

Credou, J., \& Berthelot, T. (2014). Cellulose: from biocompatible to bioactive material. J. Mater. Chem. B, 2(30), 4767-4788. https://doi.org/10.1039/C4TB00431K

Souza Lima, M. M., \& Borsali, R. (2004). Rodlike cellulose microcrystals: Structure, properties, and applications. Macromolecular Rapid Communications, 25(7), 771-787. https://doi.org/10.1002/marc.200300268

Determination of structural carbohydrates and lignin in biomass. (2012). http://www.nrel.gov/biomass/analytical_procedures.html

Dinh Vu, N., Thi Tran, H., Bui, N. D., Duc Vu, C., \& Viet Nguyen, H. (2017). Lignin and Cellulose Extraction from Vietnam's Rice Straw Using UltrasoundAssisted Alkaline Treatment Method. International Journal of Polymer Science, 2017, 1-8. https://doi.org/10.1155/2017/1063695

Gómez-Siurana, A., Marcilla, A., Beltrán, M., Berenguer, D., Martínez-Castellanos, I., \& Menargues, S. (2013). TGA/FTIR study of tobacco and glyceroltobacco mixtures. Thermochimica Acta, 573, 146-157. https://doi.org/10.1016/J.TCA.2013.09.007 
Haafiz, M. K. M., Hassan, A., Khalil, H. P. S. A., Fazita, M. R. N., Islam, Md. S., Inuwa, I. M., Marliana, M. M., \& Hussin, M. H. (2016). Exploring the effect of cellulose nanowhiskers isolated from oil palm biomass on polylactic acid properties. International Journal of Biological Macromolecules, 85, $370-378$. https://doi.org/10.1016/J.IJBIOMAC.2016.01.004

Habibi, Y., Lucia, L. A., \& Rojas, O. J. (2010). Cellulose Nanocrystals: Chemistry, Self-Assembly, and Applications. Chemical Reviews, 110(6), 3479-3500. https://doi.org/10.1021/cr900339w

Han, J., Zhou, C., Wu, Y., Liu, F., \& Wu, Q. (2013). Self-Assembling Behavior of Cellulose Nanoparticles during Freeze-Drying: Effect of Suspension Concentration, Particle Size, Crystal Structure, and Surface Charge. Biomacromolecules, 14(5), 1529-1540. https://doi.org/10.1021/bm4001734

Hosu, A., \& Cimpoiu, C. (2015). A simple tlc method for evaluation of nicotine in cigarettes. Studia UBB Chemia, 60(4), 107-114.

Iwamoto, S., Nakagaito, A. N., \& Yano, H. (2007). Nano-fibrillation of pulp fibers for the processing of transparent nanocomposites. Applied Physics A, 89(2), 461-466. https://doi.org/10.1007/s00339-007-4175-6

James F. Pankow, ${ }^{*}, \dagger$, Kelley C. Barsanti, $\uparrow$ and, \& Peyton $\ddagger$, D. H. (2002). Fraction of Free-Base Nicotine in Fresh Smoke Particulate Matter from the Eclipse "Cigarette" by 1H NMR Spectroscopy. https://doi.org/10.1021/TX020050C

Jia, X., Chen, Y., Shi, C., Ye, Y., Abid, M., Jabbar, S., Wang, P., Zeng, X., \& Wu, T. (2014). Rheological properties of an amorphous cellulose suspension. Food Hydrocolloids, 39, 27-33. https://doi.org/https://doi.org/10.1016/j.foodhyd.2013.12.026

Kalia, S., Dufresne, A., Cherian, B. M., Kaith, B. S., Avérous, L., Njuguna, J., \& Nassiopoulos, E. (2011). Cellulose-Based Bio- and Nanocomposites: A Review. International Journal of Polymer Science, 2011, 1-35. https://doi.org/10.1155/2011/837875

Kalita, R. D., Nath, Y., Ochubiojo, M. E., \& Buragohain, A. K. (2013). Extraction and characterization of microcrystalline cellulose from fodder grass; Setaria glauca (L) P. Beauv, and its potential as a drug delivery vehicle for isoniazid, a first line antituberculosis drug. Colloids and Surfaces B: Biointerfaces, 108, 8589. https://doi.org/10.1016/J.COLSURFB.2013.02.016

Kaushik, A., \& Singh, M. (2011). Isolation and characterization of cellulose nanofibrils from wheat straw using steam explosion coupled with high shear homogenization. Carbohydrate Research, 346(1), 76-85. https://doi.org/10.1016/J.CARRES.2010.10.020

Kaya, A., Hundley, M., Boydoh, A., \& Hanson, B. (2018). Characterization of tobacco stalk bleached pulp. In cellulose chemistry and technology Cellulose Chem. Technol (Vol. 52, Issue 6).

Klemm, D., Cranston, E. D., Fischer, D., Gama, M., Kedzior, S. A., Kralisch, D., Kramer, F., Kondo, T., Lindström, T., Nietzsche, S., Petzold-Welcke, K., \& Rauchfuß, F. (2018). Nanocellulose as a natural source for groundbreaking applications in materials science: Today's state. In Materials Today (Vol. 21, Issue 7). https://doi.org/10.1016/j.mattod.2018.02.001

Klemm, D., Heublein, B., Fink, H. P., \& Bohn, A. (2005). Cellulose: Fascinating biopolymer and sustainable raw material. Angewandte Chemie - International Edition, 44(22), 3358-3393. https://doi.org/10.1002/anie.200460587

Klemm, D., Kramer, F., Moritz, S., Lindström, T., Ankerfors, M., Gray, D., \& Dorris, A. (2011). Nanocelluloses: A New Family of Nature-Based Materials. Angewandte Chemie International Edition, 50(24), 5438-5466. https://doi.org/10.1002/anie.201001273

Kolakovic, R., Peltonen, L., Laaksonen, T., Putkisto, K., Laukkanen, A., \& Hirvonen, J. (2011). Spray-dried cellulose nanofibers as novel tablet excipient. AAPS PharmSciTech, 12(4), 1366-1373. https://doi.org/10.1208/s12249-011-9705-z

Kolakovic, R., Peltonen, L., Laukkanen, A., Hellman, M., Laaksonen, P., Linder, M. B., Hirvonen, J., \& Laaksonen, T. (2013). Evaluation of drug interactions with nanofibrillar cellulose. European Journal of Pharmaceutics and Biopharmaceutics, 85(3), 1238-1244. https://doi.org/10.1016/J.EJPB.2013.05.015

Kolakovic, R., Peltonen, L., Laukkanen, A., Hirvonen, J., \& Laaksonen, T. (2012). Nanofibrillar cellulose films for controlled drug delivery. European Journal of Pharmaceutics and Biopharmaceutics, 82(2), 308-315. https://doi.org/10.1016/J.EJPB.2012.06.011

Kulić, G. J., \& Radojicic, V. B. (2011). analysis of cellulose content in stalks and leaves of large leaf tobacco. Journal of Agricultural Sciences, 56(3), 207-215. https://doi.org/10.2298/JAS1103207 K

Lavoine, N., Desloges, I., Dufresne, A., \& Bras, J. (2012). Microfibrillated cellulose - Its barrier properties and applications in cellulosic materials: A review. Carbohydrate Polymers, 90(2), 735-764. https://doi.org/https://doi.org/10.1016/j.carbpol.2012.05.026

Lavoratti, A., Scienza, L. C., \& Zattera, A. J. (2016). Dynamic-mechanical and thermomechanical properties of cellulose nanofiber/polyester resin composites. Carbohydrate Polymers, 136, 955-963. https://doi.org/10.1016/J.CARBPOL.2015.10.008

Lengowski, E. C., Muniz, G. I. B. de, Nisgoski, S., \& Magalhães, W. L. E. (2013). Cellulose acquirement evaluation methods with different degrees of crystallinity. Scientia Forestalis, 41(98), 185-194. https://www.cabdirect.org/cabdirect/abstract/20133280551

Li Xiaoping, Wu Zhangkang, Y. G. (2014). Influence of the Mechanical Properties of Tobacco Stalk Fiber Cell Wall on Particleboard Panels. Advances in Materials Science and Applications, 3(1), 1-5. https://doi.org/10.5963/AMSA0301001

Lin, N., \& Dufresne, A. (2014). Nanocellulose in biomedicine: Current status and future prospect. European Polymer Journal, 59, 302-325. https://doi.org/https://doi.org/10.1016/j.eurpolymj.2014.07.025

Maafi, E. M., Malek, F., Tighzert, L., \& Dony, P. (2010). Synthesis of Polyurethane and Characterization of its Composites Based on Alfa Cellulose Fibers. Journal of Polymers and the Environment, 18(4), 638-646. https://doi.org/10.1007/s10924-010-0218-8

Macedo, V. de, Zimmermmann, M. V. G., Koester, L. S., Scienza, L. C., \& Zattera, A. J. (2017). Obtenção de espumas flexíveis de poliuretano com celulose de Pinus elliottii. Polímeros, 27(spe). https://doi.org/10.1590/0104-1428.2212 
MDIC. (2020). Exportação - Fumo em folhas e desperdícios. Ministério Do Desenvolvimento, Indústria e Comércio Exterior. http://comexstat.mdic.gov.br/pt/comex-vis

Mohanty, A. K., Misra, M., \& Drzal, L. T. (2002). Sustainable Bio-Composites from Renewable Resources: Opportunities and Challenges in the Green Materials World. Journal of Polymers and the Environment, 10(1/2), 19-26. https://doi.org/10.1023/A:1021013921916

Nogi, M., Iwamoto, S., Nakagaito, A. N., \& Yano, H. (2009). Optically Transparent Nanofiber Paper. Advanced Materials, 21(16), 1595-1598. https://doi.org/10.1002/adma.200803174

Ouajai, S., Hodzic, A., \& Shanks, R. A. (2004). Morphological and grafting modification of natural cellulose fibers. Journal of Applied Polymer Science, 94(6), 2456-2465. https://doi.org/10.1002/app.21191

Pachuau, L. S. (2015). A Mini Review on Plant-based Nanocellulose: Production, Sources, Modifications and Its Potential in Drug Delivery Applications. In Mini-Reviews in Medicinal Chemistry (Vol. 15, Issue 7, pp. 543-552). https://doi.org/http://dx.doi.org/10.2174/1389557515666150415150327

Peng, Y., Gardner, D. J., \& Han, Y. (2012). Drying cellulose nanofibrils: in search of a suitable method. Cellulose, 19(1), 91-102. https://doi.org/10.1007/s10570$011-9630-\mathrm{z}$

Peng, Y., Gardner, D. J., Han, Y., Kiziltas, A., Cai, Z., \& Tshabalala, M. A. (2013). Influence of drying method on the material properties of nanocellulose I: thermostability and crystallinity. Cellulose, 20(5), 2379-2392. https://doi.org/10.1007/s10570-013-0019-Z

Poletto, M., Zattera, A. J., \& Santana, R. M. C. (2012a). Structural differences between wood species: Evidence from chemical composition, FTIR spectroscopy, and thermogravimetric analysis. Journal of Applied Polymer Science, 126(S1), E337-E344. https://doi.org/10.1002/app.36991

Poletto, M., Zattera, A. J., \& Santana, R. M. C. (2012b). Thermal decomposition of wood: Kinetics and degradation mechanisms. Bioresource Technology, 126, 7-12. https://doi.org/10.1016/J.BIORTECH.2012.08.133

Ramiah, M. v. (1970). Thermogravimetric and differential thermal analysis of cellulose, hemicellulose, and lignin. Journal of Applied Polymer Science, 14(5), 1323-1337. https://doi.org/10.1002/app.1970.070140518

Roman, M. (2015). Toxicity of Cellulose Nanocrystals: A Review. Industrial Biotechnology, 11(1), 25-33. https://doi.org/10.1089/ind.2014.0024

Rosa, S. M. L., Rehman, N., de Miranda, M. I. G., Nachtigall, S. M. B., \& Bica, C. I. D. (2012). Chlorine-free extraction of cellulose from rice husk and whisker isolation. Carbohydrate Polymers, 87(2), 1131-1138. https://doi.org/10.1016/J.CARBPOL.2011.08.084

Segal, L., Creely, J. J., Martin, A. E., \& Conrad, C. M. (1959). An Empirical Method for Estimating the Degree of Crystallinity of Native Cellulose Using the X-Ray Diffractometer. Textile Research Journal, 29(10), 786-794. https://doi.org/10.1177/004051755902901003

Shakhes, J., Marandi, M. A. B., Zeinaly, F., Saraian, A., \& Saghafi, T. (2011). Tobacco residuals as promising lignocellulosic materials for pulp and paper industry. BioResources, 6(4), 4481-4493. https://doi.org/10.15376/biores.6.4.4481-4493

Shen, D. K., Gu, S., \& Bridgwater, A. V. (2010). The thermal performance of the polysaccharides extracted from hardwood: Cellulose and hemicellulose. Carbohydrate Polymers, 82(1), 39-45. https://doi.org/10.1016/J.CARBPOL.2010.04.018

Soni, B., Hassan, E. B., \& Mahmoud, B. (2015). Chemical isolation and characterization of different cellulose nanofibers from cotton stalks. Carbohydrate Polymers, 134, 581-589. https://doi.org/10.1016/J.CARBPOL.2015.08.031

Spence, K. L., Venditti, R. A., Rojas, O. J., Habibi, Y., \& Pawlak, J. J. (2011). A comparative study of energy consumption and physical properties of microfibrillated cellulose produced by different processing methods. Cellulose, 18(4), 1097-1111. https://doi.org/10.1007/s10570-011-9533-Z

TAPPI. (1997). T 204 cm-97 - Solvent extractives of wood and pulp.

TAPPI. (2002). T 222 om-02. Acid-insoluble lignin in wood and pulp.

Trache, D., Donnot, A., Khimeche, K., Benelmir, R., \& Brosse, N. (2014). Physico-chemical properties and thermal stability of microcrystalline cellulose isolated from Alfa fibres. Carbohydrate Polymers, 104, 223-230. https://doi.org/10.1016/J.CARBPOL.2014.01.058

Trache, D., Hussin, M. H., Haafiz, M. K. M., \& Thakur, V. K. (2017). Recent progress in cellulose nanocrystals: Sources and production. Nanoscale, 9(5), 17631786. https://doi.org/10.1039/c6nr09494e

Trache, D., Hussin, M. H., Hui Chuin, C. T., Sabar, S., Fazita, M. R. N., Taiwo, O. F. A., Hassan, T. M., \& Haafiz, M. K. M. (2016). Microcrystalline cellulose: Isolation, characterization and bio-composites application-A review. International Journal of Biological Macromolecules, 93, 789-804. https://doi.org/https://doi.org/10.1016/j.ijbiomac.2016.09.056

Trache, D., Tarchoun, A. F., Derradji, M., Hamidon, T. S., Masruchin, N., Brosse, N., \& Hussin, M. H. (2020). Nanocellulose: From Fundamentals to Advanced Applications. In Frontiers in Chemistry (Vol. 8). Frontiers Media S.A. https://doi.org/10.3389/fchem.2020.00392

Tuzzin, G., Godinho, M., Dettmer, A., \& Zattera, A. J. (2016). Nanofibrillated cellulose from tobacco industry wastes. Carbohydrate Polymers, 148, 69-77. https://doi.org/10.1016/J.CARBPOL.2016.04.045

USP 42. (2019). The United States Pharmacopeial Convention Inc. Rockville, American Pharmaceutical Association.

Vartiainen, J., Pöhler, T., Sirola, K., Pylkkänen, L., Alenius, H., Hokkinen, J., Tapper, U., Lahtinen, P., Kapanen, A., Putkisto, K., Hiekkataipale, P., Eronen, P., Ruokolainen, J., \& Laukkanen, A. (2011). Health and environmental safety aspects of friction grinding and spray drying of microfibrillated cellulose. Cellulose, 18(3), 775-786. https://doi.org/10.1007/s10570-011-9501-7 
Research, Society and Development, v. 10, n. 14, e522101422261, 2021

(CC BY 4.0) | ISSN 2525-3409 | DOI: http://dx.doi.org/10.33448/rsd-v10i14.22261

Wagner, H., \& Bladt, S. (1996). Plant Drug Analysis (Second Edition). Springer Berlin Heidelberg. https://doi.org/10.1007/978-3-642-00574-9

Wongsiriamnuay, T., \& Tippayawong, N. (2010). Non-isothermal pyrolysis characteristics of giant sensitive plants using thermogravimetric analysis. Bioresource Technology, 101(14), 5638-5644. https://doi.org/https://doi.org/10.1016/j.biortech.2010.02.037

Zanini, M., Lavoratti, A., Zimmermann, M. V., Galiotto, D., Matana, F., Baldasso, C., \& Zattera, A. J. (2017). Aerogel preparation from short cellulose nanofiber of the Eucalyptus species. Journal of Cellular Plastics, 53(5). https://doi.org/10.1177/0021955X16670590

Zimmermann, M. V., Borsoi, C., Lavoratti, A., Zanini, M., Zattera, A. J., \& Santana, R. M. (2016). Drying techniques applied to cellulose nanofibers. Journal of Reinforced Plastics and Composites, 35(8). https://doi.org/10.1177/0731684415626286 